\title{
Description of the first larval instar of Broscus crassimargo Wollaston, 1865 (Carabidae: Broscini) and notes about the presence of the species in the mesovoid shallow substratum of La Gomera (Canary Islands, Spain)
}

\author{
José D. Gilgado, Heriberto López, Pedro Oromí \& Vicente M. Ortuño
}

\begin{abstract}
Gilgado, J. D., López, H., Oromí, P. \& Ortuño, V. M. 2011: Description of the first larval instar of Broscus crassimargo Wollaston, 1865 (Carabidae: Broscini) and notes about the presence of the species in the mesovoid shallow substratum of La Gomera (Canary Islands, Spain). — Entomol. Fennica 22: 45-55.

The first larval instar of the ground beetle Broscus crassimargo Wollaston, 1865 endemic to La Gomera (Canary Islands, Spain) is described. This is the first comprehensive study of the primary chaetotaxy of the three tagmata ever carried out in larvae of Broscini, being also accompanied by a detailed iconography. The implications of the results of this chaetotaxy analysis are discussed in relation to the possible origin of Broscini within Carabidae. Comments on the ecological determinants for its remarkable presence in the mesovoid shallow substratum are given, analysing the differences between La Gomera and other Canary islands where samplings in the same subterranean habitat have been carried out.
\end{abstract}

J. D. Gilgado (corresponding author) \& V. M. Ortuño, Departamento de Zoología y Antropología Física, Facultad de Biología, Universidad de Alcalá, E28871 Alcalá de Henares, Madrid, Spain; E-mail: josedomingo.gilgado @uah.es \& vicente.ortuno@uah.es

H. López, Departamento de Biología Animal, Universidad de La Laguna, 38206 La Laguna, Tenerife, Canary Islands, Spain and Island Ecology and Evolution Research Group (IPNA-CSIC), 38206 La Laguna, Tenerife, Canary Islands, Spain; E-mail: herilope@ipna.csic.es

P. Oromí, Departamento de Biología Animal, Universidad de La Laguna, 38206 La Laguna,Tenerife, Canary Islands, Spain; E-mail: poromi@ull.es

Received 30 June 2010, accepted 29 October 2010

\section{Introduction}

The classification of the genus Broscus Panzer, 1813 and related genera has been controversial for decades. This group of ground beetles is often given the status of tribe Broscini (Britton 1949, 1964, 1970, Ball 1960, Darlington 1965, RoigJuñent 2000, Pawson et al. 2003, among others) which is equivalent to the subfamily Broscinae according to some other authors (Bousquet 2003) or even to the family Broscidae (sensu Jeannel 1941). Ball (1956) recognized three subtribes within Broscini: Broscina, Barypina and Creobiina, sections that were previously proposed by Jeannel (1941) with the status of subfamilies. Recently, Roig-Juñent (2000) proposed two subtribes more: Axonyina and Nothobroscina. The increasingly rigorous studies have 
brought a new perspective of diagnostic characters for these subtribes, and in the last analyses some genera have been relocated again (RoigJuñent 2000). Most of the taxa are unique to the Southern Hemisphere and a small part is present in the Northern Hemisphere, especially in the Palaearctic region. This distribution, and a cladistic analysis based on 73 morphological characters led Roig-Juñent (2000) to propose the origin of Broscini on the Pacific coast of Pangaea, in the early Jurassic. Although different origins have been supposed (Jeannel 1942, Britton 1949, Ball 1956, Darlington 1965, Erwin 1985), this seems to be the most parsimonious. Furthermore, a molecular analysis (Maddison et al. 1999) has also suggested a rather early divergence.

In light of the current knowledge, contrary to Bousquet (2003) and in accordance with the criterion of Roig-Juñent (2000), the Broscini of the Palaearctic region are assignable to two subtribes: Broscina and Axonyina, the latter being the most diverse and disparate. Within Broscina the genus Broscus is the most representative (25 species) and widely distributed, being present in Asia, Europe, North Africa, the Canary Islands and introduced in North America (Bousquet 2003).

The genus Broscus is represented in the Canarian archipelago by three closely related species, each one endemic to a single island: Broscus glaber (Brullé, 1836) from Gran Canaria, B. rutilans Wollaston, 1862 from Tenerife and B. crassimargo Wollaston, 1865 from La Gomera. According to Antoine (1955) and Machado (1992) they are probably related to B. politus (Dejean, 1828) from North Africa and Sicily, for having the ejaculatory duct highly sclerotized, a character absent in the remaining species of the genus. However, the shape of the Canarian species differ by their elytra being less convex and with more ovate outline (subparallel in $B$. politus) seen from above, and they are micropterous contrarily to $B$. politus, probably due to their adaptation to insular environments.

Broscus crassimargo is the largest (20-24 $\mathrm{mm}$ ), the most strictly forest-dwelling and by far the most abundant of the three Canarian species, being also different by its blackish first antennomere (dark red in the other two species) and by its duller, more flattened elytra with the lateral mar- gin perfectly reaching the basal angles of the pronotum (Wollaston 1865, Machado 1992). It is easily found practically in the whole area occupied by the "monteverde" forest (the proper laurel forest plus the so called fayal-brezal) of the central mountains of La Gomera, only avoiding the drier wooded zones facing southwards. Wollaston (1865) did not mention this detail, but it must be considered that La Gomera was the only island he never visited, having described this and many other Gomeran beetle species according to the material provided by Crotch. Both Broscus and Carabus Linnaeus, 1758 are genera with few species on the Canaries, and in the islands where they occur together they usually share habitat, probably competing for similar food resources given their comparable size and habits. The markedly higher abundance of $B$. crassimargo in respect to the other two species of Broscus could be due to the absence of Carabus in La Gomera, a genus present in Tenerife (Carabus abbreviatus Brullé, 1835 and Carabus faustus Brullé, 1839) and in Gran Canaria (Carabus coarctatus Brullé, 1839). Broscus rutilans from Tenerife is found in the marginal zones above the laurel forest (fayalbrezal), in the humid pine forest on the North of the island, and sometimes in the transition zone between the pine forest and the high mountain scrub (Machado 1992, own data). Carabus abbreviatus is also found in practically all locations where $B$. rutilans occurs, and usually more abundantly than the latter. In Gran Canaria, B. glaber is typically occurring in the mountain forest areas, mainly in more or less humid pine woods, though actually it is also found in open deforested areas. At the time of Wollaston (1864) it was also collected in former woodland sites at lower altitude like El Monte, where it does not live at present. It usually coexisted with Carabus coarctatus, but both species have become particularly scarce nowadays. In any case, $B$. crassimargo in $\mathrm{La}$ Gomera laurel forest has population densities always higher than the combined individuals of Carabus and Broscus per area in any biotope of Tenerife or Gran Canaria (own observations).

Broscus crassimargo is a species usually occurring under stones and fallen trunks, and it had also been recorded by Medina \& Oromí (1990) in the mesovoid shallow substratum (henceforth MSS; see Juberthie 1983 and Culver 2001). Me- 
dina (1991) considered that B. crassimargo had been collected in this particular subterranean habitat just occasionally. However, it has been captured repeatedly along a recent study on the arthropod fauna in the MSS of La Gomera laurel forest (unpublished own data). Most of the individuals collected in the traps are adults, but also one larva of this species has been obtained. The larva of $B$. crassimargo (as well as those of any Canarian Broscus) was previously unknown. Accordingly, larval description and its comparison with the archetypical model proposed by Bousquet \& Goulet (1984) is the main subject of the present article. This means that, after the description of $B$. cephalotes (see Luff 1978, Sharova \& Makarov 1984) and B. punctatus (see Sharova \& Makarov 1984), this is the third Broscus species on which data related to the larvae are given.

\section{Materials and methods}

\subsection{Study area and sampling method}

The sampling was carried out at Reventón Oscuro (UTM 28R 282330/3113130), a location within Garajonay National Park (La Gomera, Canary Islands) which includes one of the best representations of humid laurel forest in the archipelago. A debris mesovoid shallow substratum (MSS) (see Juberthie 1983) on a steep slope was selected, originated by colluviation at the base of rocky cliffs, but probably also increased by stony debris slipping downslope during the construction of an old forest road. These colluvia are formed by mid- to small size stones covered by a thin layer of soil, constituting a subterranean habitat with a network of abundant interstices suitable for an abundant fauna. The thickness of these colluvia is unknown, but according to our prospections when setting the traps they must reach at least $1 \mathrm{~m}$ deep. The canopy cover of the area is close to $100 \%$, evergreen trees Laurus azorica (Seub.) Franco, Ilex canariensis Poir., Picconia excelsa (Aiton) DC. and Myrica faya Aiton being the dominant species, providing a permanent penumbra to the surface and humidity to the underground layer.

Four collecting traps were set following the model described by López \& Oromí (2010). Two of them were placed five meters apart, separated two hundred meters from the other two in the same conditions. The traps were working from January 2008 to June 2010, their contents being revised twice a year (January/February and June/ July). The samples of each trap were filtered on place and kept in separate vials with propylene glycol, very appropriate to preserve the DNA of the captured individuals for genetic studies $(\mathrm{Ru}-$ bink et al. 2003).

\subsection{First instar larva of Broscus crassimargo}

A first instar larva was obtained on 04/01/2010. This larva was dissected, extracting the labium, mandibles, maxillae, antennae, cephalic capsule sclerites, legs, and tergal and sternal sclerites by using dissection tweezers. These pieces were soaked in the water-soluble resin Dimethyl Hydantoin Formaldehyde (DMHF) (Steedman 1958) and placed on acetate sheets for use as microscope slides, which measured $1.5 \times 0.5 \mathrm{~cm}$. Another small acetate sheet was placed on each slide as a cover slip for observation under the microscope. The microscope slides with the larvae dissected are deposited at Vicente M. Ortuño's (VMO/AU) collection at the Department Zoology and Physical Anthropology of the University of Alcalá.

The habitus was drawn using a NIKON SMZ1000 stereoscopic binocular microscope. Each preparation was observed and measured with an optical microscope ZEISS 474620-9900, with camera lucida and a calibrated ocular micrometer. The habitus and preparations were drawn in ink. The drawings were scanned and labelled using the application Adobe Photoshop Cs 8.0.

The adopted nomenclature for the setae and pores is that proposed by Bousquet \& Goulet (1984). According to this criterion, setae are named with numbers, and pores with letters. The supernumerary setae are named with Roman numbers, and supernumerary pores with Greek letters, when they are present.

In some parts of the anatomy of the larva it was impossible to identify some particular pores, since more than one of those were found in the same area where they should be located, according to the archetype proposed by Bousquet \& 
Table 1. No. of Broscus crassimargo adults and one larva collected in the traps.

\begin{tabular}{lc}
\hline Sampling period & No. \\
\hline $04 / 01 / 2008-01 / 07 / 2008$ & 1 \\
$01 / 07 / 2008-01 / 02 / 2009$ & 15 \\
$01 / 02 / 2009-30 / 06 / 2009$ & 4 \\
$30 / 06 / 2009-04 / 01 / 2010$ & $18+1$ larva \\
$04 / 01 / 2010-08 / 06 / 2010$ & 1 \\
\hline
\end{tabular}

Goulet (1984). In such cases, the application of the terminology for groups of structures was chosen, as it had been occasionally done with some setae. Examples are the groups of pores gPRi, gPRj, gMEe, among others.

\section{Results}

\subsection{Collected Broscus crassimargo and other invertebrates}

In this study 39 adults and one larva of $B$. crassimargo were captured in the MSS traps, but in different numbers depending on the sampling period, so that the total specimens (Table 1) collected in each period is higher in the second half of each year. Besides $B$. crassimargo, we collected in these traps a wide range of invertebrates that occupy the underground habitat of this area, varying from species with marked subterranean adaptations to non-adapted species that venture underground occasionally or accidentally. The beetles Pseudoplatyderus amblyops Bolívar, 1940, Domene jonayi Hernández \& Medina, 1990 and Euconnus specusus Vit, 2004, and the millipede Glomeris canariensis Golovatch, 1987 stand out in the first group. Several edaphobionts with a lower degree of subterranean adaptation were also collected, particularly the beetle Aeletes gemmula (Wollaston, 1865) and the millipede Blaniulus sp. besides abundant oribatid mites. Finally, the humicolous and epiedaphic species were the richest and most diverse group collected in these traps, with a notable abundance of Plutonia oromii (Ibáñez \& Alonso, 1988) (Pulmonata), Brachydesmus sp. (Polydesmida), Eluma caelata (Miers, 1877) (Isopoda), Gomerina calathiformis (Wollaston, 1865) (Coleoptera)
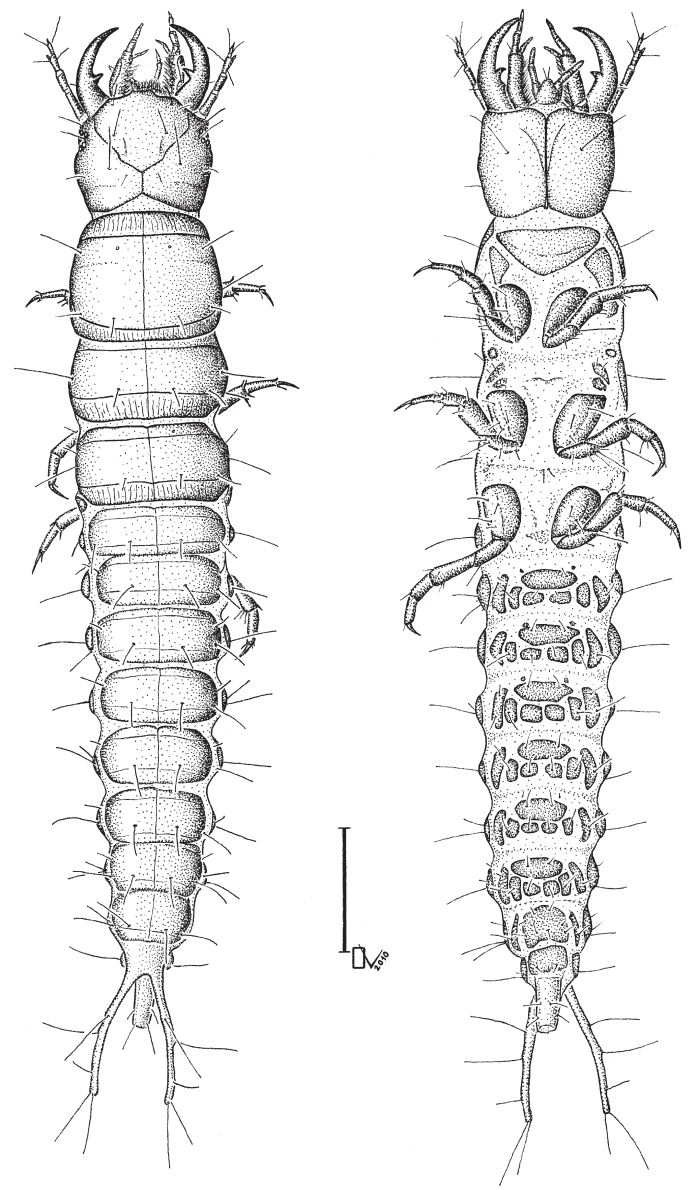

Fig. 1. Habitus of the first instar larva of $B$. crassimargo. Scale bar $2 \mathrm{~mm}$.

and Aptilotus sp. (Diptera). Other epiedaphic carabids like Calathus laureticola Wollaston, 1865, Trechus flavocinctus gomerae Jeannel, 1936, Paraeutrichopus harpaloides (Wollaston, 1864) and Dicrodontus aptinoides (Wollaston, 1865) were collected occasionally. However, epigean species of Calathus Bonelli, 1810 and Cymindis Latreille, 1806 frequently found on the surface around the traps were never caught in these MSS samples.

\subsection{Description of the first instar larva of Broscus crassimargo}

Habitus (Fig. 1). Dark brown to reddish larva, $18.7 \mathrm{~mm}$ long from the nasale to the apex of pygidium. Massive head (almost as wide as the pronotum), body gradually tapering backwards, 
Fig. 2. First instar larva of $B$. crassimargo. Cephalic pieces. $-a$.

Frontale. - b. Parietal in dorsal view. - c. Parietal in ventral view. - d. Labium in dorsal view. - e. Right maxilla in dorsal view. $-f$. Right maxilla in ventral view. - g. Right mandible in dorsal view. - h. Right antenna in dorsal view. $-i$. Right antenna in ventral view. Scale bars, a-c: $1 \mathrm{~mm}$; d-f: $0.5 \mathrm{~mm} ; \mathrm{g}: 1 \mathrm{~mm}$; h-i: $0.5 \mathrm{~mm}$.

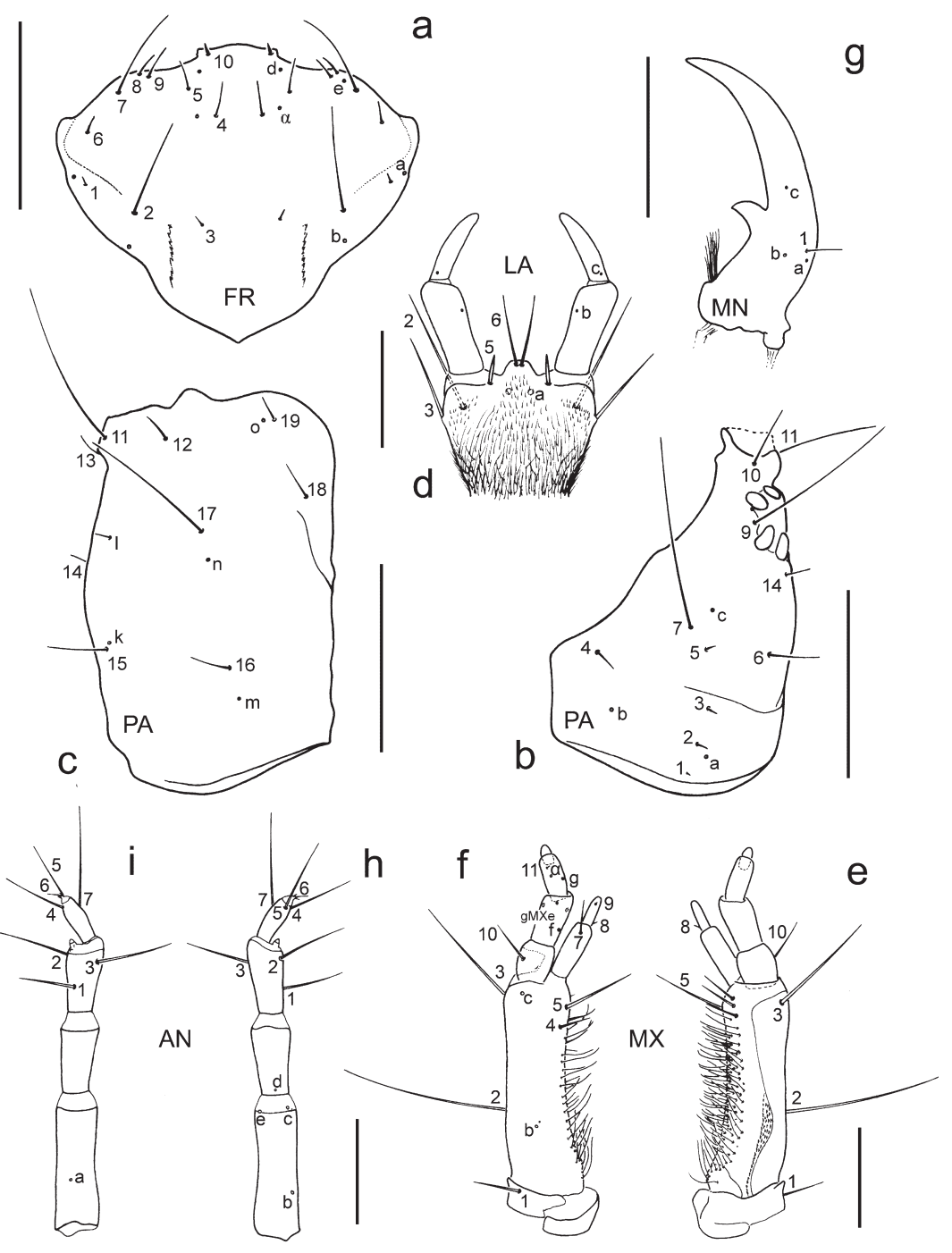

as in the third instar of Broscus cephalotes according to the description by Luff (1993); relatively short legs.

Cephalic capsule. Epicranial suture less than a third of the frontale length. Frontale almost triangular, $1.61 \mathrm{~mm}$ long and $1.98 \mathrm{~mm}$ wide (Fig. 2a). It bears ten setae (FR1-FR10) and five distinguishable pores (FRa-FRd) at each side of the sagittal plane, one of them supernumerary $(\mathrm{FR} \alpha)$, and lacking FRc. There are two egg bursters. The nasale is almost flat, but slightly curved and slightly acuminate at the extremes. Parietale (Figs. 2b,c) with six stemmata around the ocular protuberance. The parietale has a conspicuous lateral constriction, and bears eighteen setae
(PA1-PA19), lacking seta PR8, but with one supernumerary PRI. There are only eight distinguishable pores (PAa-PRd, PRk, PRm-PRo). Labium (Fig. 2d) with three pores (LAa-LAc) and only four distinguishable setae (LA2-LA3, LA5-LA6); it is so pubescent dorsally that the setae LA1 and LA4 are indistinguishable. There is a very short protuberance, corresponding to the ligula, with two setae (LA6) almost as long as the last labial palpomere. Maxillae (Figs. 2e,f) approximately $1.86 \mathrm{~mm}$ in length, pubescent in the inner dorsal face. Palp cylindrical, with four palpomeres. Galea with two galeomeres, approximately as long as the two first palpomeres. Lacinia absent. The maxilla bears ten setae 


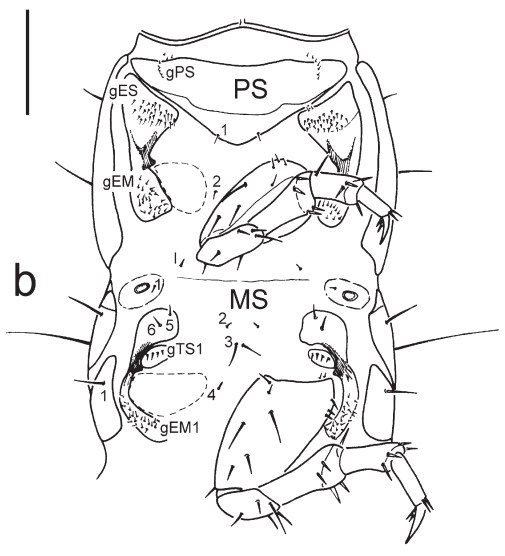

d
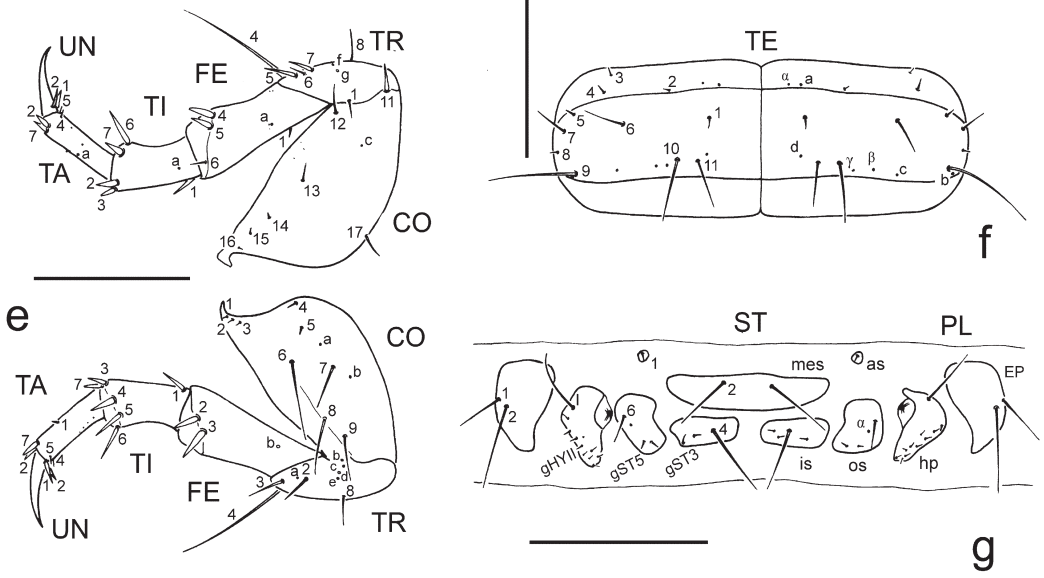
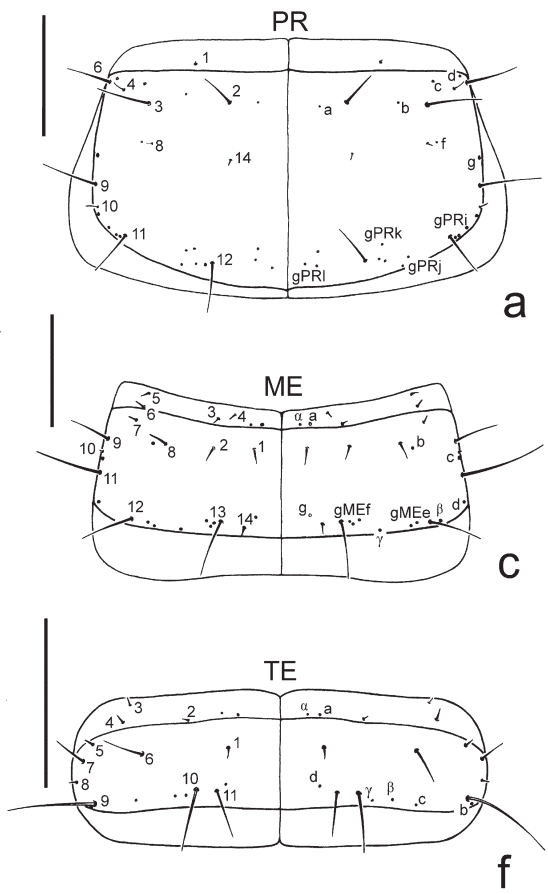

Fig. 3. First instar larva of $B$. crassimargo. - a. Pronotum. - b. Prothorax and mesothorax in ventral view. - c. Mesonotum. - d. Prothoracic right leg. - e. Prothoracic right leg. $-\mathrm{f}$. Abdominal tergite-l. -g. Sternite and pleurites extended of abdominal segment-I. Scale bar: $1 \mathrm{~mm}$.
(MX1-MX11), MX6 indistinguishable because of the pubescence, and MX12 absent; and eight pores (MXb-MXc, gMXe, MXf-MXg) with a supernumerary pore in the third palpomere $(\mathrm{MX} \alpha)$, in the relative position of MXe there are three pores (gMXe) and the pore MXa is absent. Mandible sharp, long (1.69 $\mathrm{mm}$ in length) and curved (Fig. 2g), with one seta (MN1) and three pores $(\mathrm{MNa}-\mathrm{MNc})$. It bears a short but sharpened retinaculum. Antennae (Figs. 2h,i) $1.66 \mathrm{~mm}$ long, with four antennomeres, and a sensory appendage on the third one; it bears seven setae (AN1AN7), with AN6 very reduced and only five pores (ANa-ANe), since ANf and $\mathrm{ANg}$ are absent.

Thorax. In all thoracic tergites there is a visible medial suture. Pronotum (Fig. 3a) $2.22 \mathrm{~mm}$ in length and $3.37 \mathrm{~mm}$ in width, with a lateral constriction approximately in the first third, bearing eleven setae (PR1-PR14), PR5, PR7 and PR13 absent; and eighteen pores (PRa-PRg): PRe and $\mathrm{PRh}$ are absent, but in the relative position of PRi, PRj, PRk and PRl there are groups of pores (gPRi-gPRl) several pores. Prosternum (Fig. 3b) with gPS, PS1 and PS2 present. Episternum (ES) and epimeron (EM) fused, with a sclerotized region between them, each one bearing a group of setae (gES and gEM). Mesonotum (Fig. 3c) 1.40 $\mathrm{mm}$ in length and $3.22 \mathrm{~mm}$ in width, bearing fourteen setae (ME1-ME14) and thirteen pores (MEa-gMEl); there are several supernumerary pores, the ME $\alpha$ and, similarly to the pronotum, groups of pores (gMEe and gMEf) in the relative position of the pores MEe and MEf. Mesosternum bearing six setae (MS1-MS6), trochantin with a group of four setae (gTS1) and epimeron with a numerous group of setae (gEM1). Pleuron with a long seta (PL1). 
Fig. 4. First instar larva of $B$. crassimargo. - a. Urogomphi in dorsal view. - b. Pygidium in dorsal view. - c. Pygidium in ventral view. Scale bar: $1 \mathrm{~mm}$.

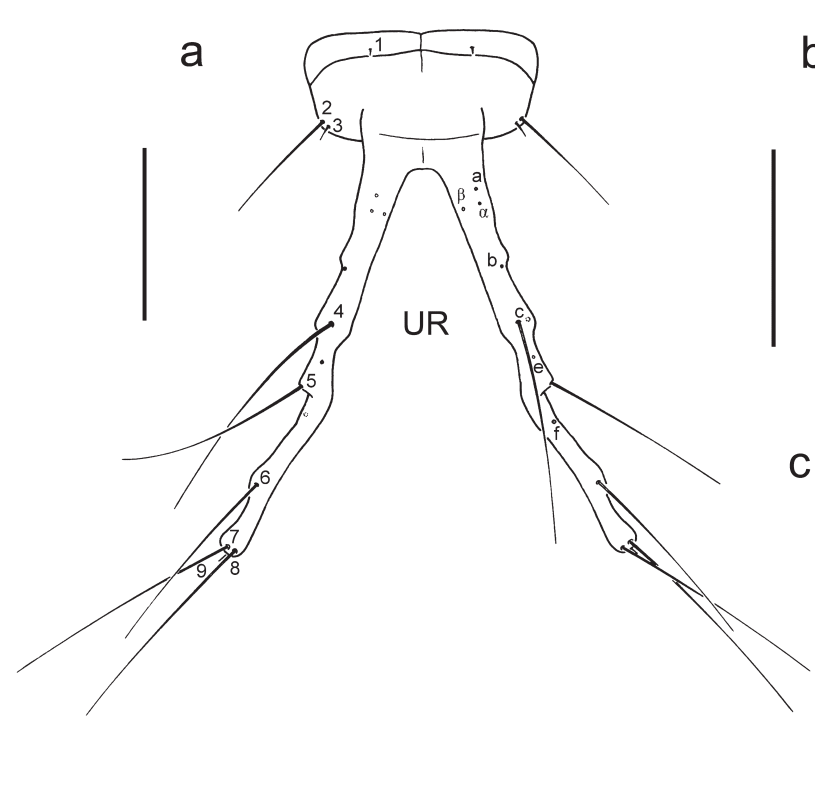

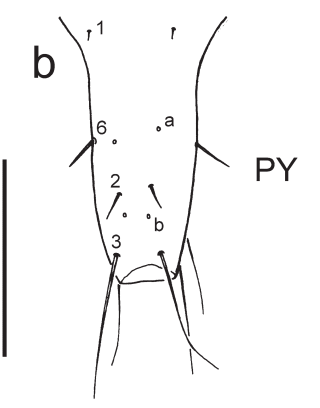

C
Legs (Figs. 3d,e). Similar in size and chaetotaxy, with one claw, less pigmented than tergites, and relatively short measuring $4.23 \mathrm{~mm}$ approximately from the basis of the coxa to the tip of the claw. The description is based on the prothoracic leg. Coxa with sixteen setae (CO1-CO17), lacking $\mathrm{CO} 10$. Three visible pores $(\mathrm{COa}-\mathrm{COc})$. Trochanter with eight setae (TR1-TR8), and seven pores $(\mathrm{COa}-\mathrm{COg})$. Femur bearing seven setae (FE1-FE7) and two pores (FEa and FEc). Tibia with seven setae (TI1-TI7) and two pores (TIaTIb). Tarsus with five setae (TA1-TA7), lacking TA3 and TA6; setae TA4 and TA5 very reduced. Claw with two conspicuous setae (UN1 and UN2).

Abdomen. Length approximately $10.37 \mathrm{~mm}$, measured from the first abdominal segment to the end of the pygidium. The abdominal tergite-I (Fig. 3f) is $0.94 \mathrm{~mm}$ in length and 2.61 in width. It bears eleven setae (TE1-TE11) and seven clearly distinguishable pores, (TEa-TEd) and three supernumerary (TE $\alpha-T E \gamma)$. The sternites of abdominal segment-I (Fig. 3g) with four setae (ST1, ST2, ST4 and ST6), and two groups of supernumerary setae (gST3 and gST5) in the relative position of ST3 and ST5 respectively. There is a pore ST $\alpha$. The epipleurite bears two setae (EP1 and EP2). Hypopleurite with a well developed seta HPI, and a group of setae gHPII. There is also a conspicuous spiracle, which is not present in the rest of abdominal segments. The urogomphi (Fig. 4a) are $2.75 \mathrm{~mm}$ long, similar to the model of Bousquet \& Goulet (1984), bearing nine setae (UR1-UR9) and seven pores: (URa-URf), with URd and URg absent, and two supernumerary (UR $\alpha$ and UR $\beta$ ). Pygidium (Figs. 4b,c) $1.36 \mathrm{~mm}$ in length and $0.53 \mathrm{~mm}$ in width approximately, bearing seven setae (PY1-PY7), lacking PY4 and PY5, and including two supernumerary (PYI and PYII). There are six pores: (PYa, PYb and $\mathrm{PYf})$, three of them supernumerary (PY $\alpha-\mathrm{PY} \gamma)$.

\section{Discussion}

\subsection{First instar larva of Broscus crassimargo}

The effectiveness of larval characters to build a precise beetle systematics has already been demonstrated (Beutel 1993, Solodovnikov 2007). This is the reason whereby more and more specific studies on larval characters have been incorporated to the first treatises and compendia on Coleoptera larvae. Preimaginal characters provide a great deal of anatomical information, in addition to those already available on the imagos. Clearly, the larva is very relevant for systematics as it is another genotypic expression of the spe- 
cies (Goulet 1979, Luff 1993) and from the ecological point of view, they often occupy different niches and can exploit different food resources. For this reason, the selective pressures do not need to be the same in larval and adult stages, and the preimaginal instars can show very different evolutionary rhythms than the imagoes. As a result, they can show already "lost" features in the imagoes, which could help to infer the phylogenetic relationships of species.

However, the study of preimaginal morphology poses a series of difficulties (Solodovnikov 2007) which are, of course, also present in the study of the larva of $B$. crassimargo: a) the low number of specimens in collections, $b$ ) the need to dissect and make preparations for microscopic observation of some structures, c) the existence of intraspecific variability in some characters such as chaetotaxy (in case of a single specimen may be discernible by asymmetry on both sides of the sagittal plane), and d) the difficulty of determining whether a character is homologous or not in several taxa.

The finding and study of the present larva of $B$. crassimargo is a return to the incipient research line on the preimaginal stages of the endemic Canarian Carabidae (see Raynaud 1970, Arndt 1991). According to Machado (1992), this line of research has only two earlier contributions: one concerning Carabus abbreviatus (Carabinae) and the other to Zargus crotchianus Wollaston, 1865 (Licininae).

Furthermore, the description of this larva becomes important from a methodological point of view, since though other Broscini larvae have already been described (Gardner 1931, Jeannel 1941, Moore 1964, Andersen 1968, Harris 1978, 1980, Luff 1978, 1993, Townsend 1971, 1988, Sharova \& Makarov 1984, Arndt 1991, Davidson $\&$ Ball 1998), this is the first species of this tribe in which the nomenclatorial criterion of Bousquet \& Goulet (1984) is applied, as done by Arndt (1991) for the description of Zargus crotchianus. This will allow a more precise comparison with other Carabidae larvae and also with the archetype proposed by Bousquet \& Goulet (1984).

So far, the most and best studied Broscini larva is that of B. cephalotes (Jeannel 1941, Luff 1978, 1993, Sharova \& Makarov 1984). However, given that the described larva of B. cepha- lotes is a third instar larva, and that of $B$. crassimargo a first instar, the differences between them could be due to their different stages of development and therefore would not be useful for specific discrimination, therefore those differences are not presented here. However, the study of chaetotaxy in the first stage of $B$. cephalotes using the criterion of Bousquet \& Goulet (1984), most likely would reveal more significant differences with respect to $B$. crassimargo.

The study of the larva of $B$. crassimargo has revealed an extraordinary resemblance (number and topology of pores and sensory setae) to the model of Bousquet \& Goulet (1984), although they did not use any species of Broscini that contributed with its characters to the archetypical proposal. This relates to the primitiveness of this group of Carabidae. Very probably the divergence of the Broscini from other Carabidae had a very basal origin, and so they could have retained much of the early larval characters. This evidence coming from the study of larval chaetotaxy is supported by other studies on imaginal morphology (Roig-Juñent 2000), and molecular biology (Maddison et al. 1999).

It is possible that the species of this lineage have maintained a lifestyle very similar to primitive species, not being necessary to adapt too radically to different living conditions, thus preventing remarkable structural changes (apomorphies). In relation to this, Erwin (1985) postulates that the first ground beetles were natural of high humidity, or water-related environments, as suggested by its relationship to other Adephaga like Dytiscidae, and their almost anecdotal presence in the most xeric areas of the planet. Thus, this environment would have been the evolutionary centre of dispersal, and therefore in the most primitive groups tend to be organically linked to humid environments (coasts, riparian and marsh areas, wooded areas, etc.).

\subsection{The occurrence of Broscus crassimargo in the MSS}

The presence of certain epigean species in the Canarian MSS is a constant feature in the few studies carried out so far in this environment (Medina 1991, Medina \& Oromí 1990, Oromí et al. 
1986, own data), including some medium to large size beetles (Carabidae and Staphylinidae) like Broscus, Carabus, Ocypus Leach, 1819 and Protogoerius Coiffait, 1956. But such species occur particularly in the MSSs with more interstitial profusion, usually coinciding with those of colluvial origin (debris MSS). Contrarily, the MSS formed by volcanic clinker is usually more isolated from the surface and their interstices are more sealed, consequently being less practicable for big epigean species usually larger than those adapted to live underground.

As we have observed along years of studies on this subterranean fauna (unpublished data) Broscus and Carabus have some tendency to enter in such colluvia. However, no Broscus have ever been collected in the MSS of Tenerife or Gran Canaria, while the local species of Carabus were sometimes present (occasionally even abundant in certain traps in Tenerife). The presence of B. crassimargo in the MSS of La Gomera could suggest that, given the absence of Carabus in this island, the former has occupied a niche not available in the other two islands due to the competition of Carabus. The absence of large sized troglobitic ground beetles probably favours that Broscus and Carabus invade temporarily the underground to exploit an empty niche. Instead, in the present case study in La Gomera there is a poor representation of mid to small size epigean ground beetles with the exception of Gomerina calathiformis, a species with clear tendency to invade shallow underground layers and already captured by Medina (1991) in the MSS of this island. This scarcity must be due to the abundance of the troglobitic Pseudoplatyderus amblyops in the samples, a blind $9 \mathrm{~mm}$ long ground beetle which is by far the most abundant (as much as 247 individuals collected) among any size category.

Probably both Broscus and Carabus invade the MSS following preys such as slugs that need high humidity, always present in the MSS but only seasonally on the surface. This could explain why the number of Broscus collected in the MSS at Reventón Oscuro laurel forest was much higher in the summer/fall than in the more humid winter. On the contrary, after an analysis of surface records of $B$. crassimargo in the laurel forest of Gomera, Machado (1992) pointed out that it was more abundant in the first half of the year (winter/spring), a more humid period when potential prey are abundant in epigean environments. A similar pattern of captures has been observed in the predatory beetles Euconnus specusus and Ocypus silvaticus Wollaston, 1865. Probably the latter is more abundant in the summer/autumn for the same reasons as $B$. crassimargo, but the abundance of $E$. specusus is probably related to its natural phenology, since it is a troglobiont beetle which permanently occupies an underground layer hardly influenced by seasonal changes.

It is stated that $B$. crassimargo occurs rather frequently in the MSS here studied, but it is not clear whether they just occupy shallow layers or reach deeper levels of the colluvium. The trap model we have used works identically for a rank between 15 and $80 \mathrm{~cm}$. To solve this question it would be necessary to use a selective trap for different depths (see Schlick-Steiner \& Steiner 2000, Laška et al. 2008, in press).

Larvae of Carabus or Broscus had never been captured before in the MSS of the Canary Islands, for which probably their presence in this environment could be occasional, contrarily to the adults, which are relatively common as commented above. According to the ecological classification proposed by Sharova (2008), the larvae of Broscus are geobionts belonging to the "burrowing forms", and this soil burrowing lifestyle is also confirmed by the morphology of their thoracic endoskeleton (Zaitsev 2008), so maybe setting traps in the proper soil around the sites where $B$. crassimargo has been obtained in the MSS, could be useful to check their endogean or hypogean preferences. The latter is less probable since debris MSS sites are not easy to find and probably represent a minimum part of the total distributional area of the species in La Gomera.

Acknowledgements. We want to thank Verónica González Araujo for revising the grammar and for her suggestions with the English. This study has been partially financed by the I3 program of "Incentivation of the Incorporation and Intensification on Research Activity of the Ministry of Education and Science of Spain, of which Vicente Ortuño is the beneficiary, and by the $025 / 2007$ research project of the also Spanish Ministry of Natural, Rural and Marine Environment carried out by P. Oromí, H. López and collaborators in Garajonay National Park. 


\section{References}

Andersen, J. 1968: The larva of Miscodera arctica Payk. (Col., Carabidae). - Norsk Entomologisk Tidsskrift 15: 71-74.

Antoine, M. 1955: Coléoptères Carabiques du Maroc (1ère partie). - Mémoires de la Société de Sciences Naturelles et Physiques du Maroc, Zoologie (Nouv. Série) 1: 1-177. [In French.]

Arndt, E. 1991: Beitrag zur Kenntnis der Licinini-Larven (Coleoptera, Carabidae). - Entomologische Nachrichten und Berichte 35: 117-122. [In German.]

Ball, G. E. 1956: Notes on the genus Zacotus La Conte, 1869 , and the classification of the tribe Broscini (= Broscidae sensu Jeannel, 1941. Coleoptera, Carabidae). - The Coleopterists Bulletin 10(3): 33-52.

Ball, G. E. 1960: Carabidae (Latreille, 1810); the ground beetles. Fascicle 4. - In: Arnett, R. H. (Editor and principal author), The beetles of the United States: 55182. The Catholic University of America Press, Washington, D. C. xi +1112 pp.

Beutel, R. G. 1993: Phylogenetic analysis of Adephaga (Coleoptera) based on characters of the larval head. Systematic Entomology 18: 127-147.

Bousquet, Y. 2003: Carabidae: Broscinae. — In: Löbl, I. \& Smetana, A. (eds.), Catalogue of Palaearctic Coleoptera. Vol. 1: 235-237. Apollo Books, Stenstrup. 819 pp.

Bousquet, Y. \& Goulet, H. 1984: Notation of primary setae and pores on larvae of Carabidae (Coleoptera: Adephaga). - Canadian Journal of Zoology 62: 573-588.

Britton, E. B. 1949: The Carabidae (Coleoptera) of New Zealand. Part 3. A revision of the Tribe Broscini. Transactions of the Royal Society of New Zealand 77: 533-581.

Britton, E. B. 1964: New Carabidae (Coleoptera) from Three Kings Islands, New Zealand. — New Zealand Journal of Science 7: 521-527.

Britton, E. B. 1970: Coleoptera (Beetles). — In: Waterhouse, D. F. (ed.), The insects of Australia: 495-621. Melbourne University Press. Canberra. 1029 pp.

Culver, D. C. 2001: Subterranean ecosystems. - Encyclopedia of Biodiversity 5: 527-540.

Davidson, R. L. \& Ball, G. E. 1998: The tribe Broscini in Mexico: Rawlinsius papillatus, new genus and new species (Insecta: Coleoptera: Carabidae) with notes on natural history and evolution. - Annals of Carnegie Museum 67: 349-378.

Darlington, P. J. J. 1965: Biogeography of the southern end of the World. Distribution and History of far southern life and land, with an assessment of continental drift. —Cambridge MA: Harvard University Press. 236 pp.

Gardner, J. C. M. 1931: Immature stages of Indian Coleoptera (8), (9). - Indian Forest Records (Entomology Series) 16: 49-89; 91-111.

Erwin, T. L. 1985: The Taxon pulse: a general pattern of lineage radiation and extinction among carabid beetles. - In: Taxonomy, Phylogeny and Zoogeography of beetles and ants: 437-472. Dr W. Junk Publishers. Dordrecht. xiii +514 pp.
Goulet, H. 1979: Contributions of characters of larvae to systematics of Carabidae. - In: Erwin, T. L., Ball, G. E., Whitehead D. R. \& Harpen A. L. (eds.), Carabid beetles: their evolution, natural history and classification: 205-208. Dr. Junk bv Publ., The Hage.

Harris, A. C. 1978: The Larva of Brullea antarctica (Coleoptera: Carabidae: Broscinae). — The New Zealand Entomologist 6: 401-405.

Harris, A. C. 1980: The Larva of Brullea antarctica (Coleoptera: Carabidae: Broscinae): Note. — The New Zealand Entomologist 7: 174-175.

Jeannel, R. 1941: Faune de France, 39. Coléoptères Carabiques. Première partie. - Lechevalier, Paris. 571 pp. [In French.]

Jeannel, R. 1942: La genèse des faunes terrestres: éléments de biogéographie. - Presses Universitaires de France. 513 pp. [In French.]

Juberthie, C. 1983: Le milieu souterrain: étendue et caractéristiques. - Mémoires de Biospéologie 10: 17-65. [In French.]

Laška, V., Mikula, J., Růžička, V., Véle, A., Šarapatka, B. \& Tuf, I.: Depth distribution of spiders in soil profile. - Journal of Arachnology. (In press.)

Laška, V., Mikula, J. \& Tuf, I. H. 2008: Jak hluboko žijí půdní bezobratlí? [How deep do soil invertebrates live?] - Živa 56: 169-171. [In Czech.]

López, H. D. \& Oromí, P. 2010: A pitfall trap for sampling the mesovoid shallow substratum (MSS) fauna. Speleobiology Notes 2: 7-11.

Luff, M. L. 1978: The larvae of the British Carabidae (Coleoptera) V. Omophronini, Loricenini, Scaritini and Broscini. — Entomologist's Gazette 29: 265-287.

Luff, M. L. 1993: The Carabidae (coleoptera) larvae of Fennoscandia and Denmark. - Fauna Entomologica Scandinavica 27: 1-187.

Machado, A. 1992: Monografía de los carábidos de las Islas Canarias. — Instituto de Estudios Canarios. La Laguna, 734 pp. [In Spanish.]

Maddison, D. R., Baker, M. D. \& Ober, K. A. 1999: Phylogeny of carabid beetles as inferred from $18 \mathrm{~S}$ ribosomal DNA (Coleoptera: Carabidae). — Systematic Entomology 24: 103-138.

Medina, A. L. 1991: El medio subterráneo superficial en las Islas Canarias: caracterización y consideraciones sobre su fauna. — Ph.D. thesis, Universidad de La Laguna. Tenerife. [In Spanish.]

Medina, A. L. \& Oromí, P. 1990: First data on the superficial underground compartment on La Gomera (Canary Islands). - Mémoires de Biospéologie 17: 87-91.

Moore, B. P. 1964: Australian larval Carabidae of the Subfamilies Broscinae, Psydrinae and Pseudomorphinae (Coleoptera). — Pacific Insects 6: 242-246.

Oromí, P., Medina, A. L. \& Tejedor M. L. 1986: On the existence of a superficial underground compartment in the Canary Islands. - Actas del IX Congreso Internacional de Espeleología, Barcelona 2: 147-151.

Pawson, S. M., Emberson, R. M., Armstrong, K. F. \& Paterson, A. M. 2003: Phylogenetic revision of the endemic New Zealand carabid genus Oregus Putzeys (Co- 
leoptera: Carabidae: Broscini). — Invertebrate Systematics 17: 625-640.

Raynaud, R. 1970: Stades larvaires n ${ }^{\circ}$ 21. Planche XCII A: Genus Nesaeocarabus sp. interruptus. - Bulletin mensuel de la Société linnéenne de Lyon 39: 166-177. [In French.]

Roig-Juñent, S. 2000: The Subtribes and Genera of the tribe Broscini (Coleoptera: Carabidae): cladistic analysis, taxonomic treatment, and biogeographical considerations. - Bulletin of the American Museum of Natural History 225: 1-90.

Rubink W. L., Murray, K. D., Baum, K. A. \& Pinto, M. A. 2003: Long term preservation of DNA from honey bees (Apis mellifera) collected in aerial pitfall traps. The Texas Journal of Science 55: 159-168.

Schlick-Steiner, B. C. \& Steiner, F. M. 2000: Eine neue Subterranfalle und Fänge aus Kärntnen. - Carinthia II 190: 475-482. [In German.]

Sharova, I. K. 2008: Adaptative radiation of carabid larvae (Coleoptera, Carabidae). — In: Penev, L., Erwin, T. L. \& Assman, T. (eds.), Back to the roots and back to the future. Towards a new synthesis amongst taxonomic, ecological and biogeographical approaches in carabidology: 285-304. Proceedings of the XIII European Carabidologists Meeting. Pensoft Publishers, Blagoevgrad.

Sharova, I. K. \& Makarov, K. V. 1984: Larvae of carabids of the genus Broscus Panz. (Coleoptera, Carabidae). — Entomologicheskoe Obozrenie 63: 742-750.
Solodovnikov, A. Y. 2007: Larval chaetotaxy of Coleoptera (Insecta) as a tool for evolutionary research and systematics: less confusion, more clarity. - Journal of Zoological Systematics and Evolutionary Research 45: $120-127$.

Steedman, H. F. 1958: Dimethyl Hydantoin Formaldehyde: a new water-soluble resin for use as a mounting medium. - Quaterly Journal of Microscopical Science 99: 451-452.

Townsend, J. I. 1971: Entomology of the Aucklands and other islands of New Zealand: Coleoptera: Carabidae: Broscini. - Pacific Insects Monograph 27: 173-184.

Townsend, J. I. 1988: Larva of Bountya insularis Townsend (Coleoptera: Carabidae). — New Zealand Entomologist 11: 9-11.

Wollaston, T. V. 1864: Catalogous of the coleopterous insects of the Canaries in the collection of the British Museum. - Taylor \& Francis, London, 648 pp.

Wollaston, T. V. 1865: Coleoptera Atlantidum. — John van Voorst, London, 526 pp (app. 140 pp.).

Zaitsev, A. A. 2008: Thoracic endoskeleton of carabid larvae (Coleoptera, Carabidae). - In: Penev, L., Erwin, T. L. \& Assman, T. (eds.), Back to the roots and back to the future. Towards a new synthesis amongst taxonomic, ecological and biogeographical approaches in carabidology: 159-171. Proceedings of the XIII European Carabidologists Meeting. Pensoft Publishers, Blagoevgrad. 